\title{
The Gene Expression Profile of Cyst Epithelial Cells in Autosomal Dominant Polycystic Kidney Disease Patients
}

\author{
Jae Eun Lee, Min Ha Park and Jong Hoon Park* \\ Department of Biological Science, Sookmyung Womens University, Seoul 140-742, Korea
}

Received 30 January 2004, Accepted 14 May 2004

\begin{abstract}
Autosomal dominant polycystic kidney disease (ADPKD) is a common genetic disorder characterized by the formation of fluid-filled cysts in the kidney and progressive renal failure. Other manifestations of ADPKD include the formation of cysts in other organs (liver, pancreas, and spleen), hypertension, cardiac defects, and cerebral aneurysms. The loss of function of the polycystin -1 and -2 results in the formation of epithelium-lined cysts, a process that depends on initial epithelial proliferation. cDNA microarrays powerfully monitor gene expression and have led to the discoveries of pathways regulating complex biological processes. We undertook to profile the gene expression patterns of epithelial cells derived from the cysts of ADPKD patients using the cDNA microarray technique. Candidate genes that were differently expressed in cyst tissues were identified. 19 genes were up-regulated, and 6 down-regulated. Semi-quantitative RT-PCR results were consistent with the microarray findings. To distinguish between normal and epithelial cells, we used the hierarchical method. The results obtained may provide a molecular basis for understanding the biological meaning of cytogenesis.
\end{abstract}

Keywords: ADPKD, Expression profile, Microarray, RT-PCR

\section{Introduction}

Autosomal dominant polycystic kidney disease (ADPKD) is a hereditary disease that occurs in one out of 1,000 humans (Michael et al., 2000; Guanqing, 2001). ADPKD forms cysts in the kidney, liver, and pancreas, which result in cardiac defects (Boulter, 2001). In addition, ADPKD causes chronic renal failure in approximately $50 \%$ of patients by age 60 . The

*To whom correspondence should be addressed.

Tel: 82-2-710-9414; Fax 82-2-2077-7322

E-mail: parkjh@sookmyung.ac.kr disease is generally attributed to a mutation in PKD1 or PKD2 which encode polycystin-1 or 2 (van Adelsberg, 1999; Guanqing, 2000; Guanqing, 2001; Silvia et al., 2001). ADPKD is caused by a mutation in PKD1 in about $85 \%$ of cases and a mutation in PKD2 in the remaining 15\% (Michael et al., 2000; Guanqing, 2001). Polycystin-2 is an integral membrane protein (968 amino acids) with 6 membrane spanning domain, and intracellular C-terminal contains a calcium-binding EF-hand (Hanaoka et al., 2000). Polycystin-1 and 2 interact with the coiled-coil domain of intracellular Cterminal and thus form a calcium-permeable non-selective cation current. However, the mechanistics and functions of polycystin-1 and 2 are largely unknown.

Presently, cDNA microarray technologies are used to study disorders at the molecular level (Makaki et al., 2001). The technique allows the characterization of the expression patterns of numerous genes in a single microarray (Schena et al., 1995; Derisi et al., 1996; Lockhart et al., 1996; Quackenbush, 2002). Generally, the spots and background intensities of a microarray TIFF image file are analyzed and normalized to generate a gene expression pattern. Here, we used a cDNA microarray to identify the gene expression profile of cyst epithelial cells in ADPKD patients.

\section{Material and Methods}

Cell culture Kidney cyst tissues of two ADPKD patients were obtained from the Seoul Medical School. Epithelial cells were isolated from the cysts as follows. Cysts were washed with PBS solution, cut into pieces with a knife, and FBS added. Cells thus prepared were incubated at $37^{\circ} \mathrm{C}$ in DMEM medium. After 2-4 passages, cyst and normal renal epithelial cells (Cambrex Co. Beverly Hills, USA) were cultured in REGM medium (Cambrex Co.) at $37^{\circ} \mathrm{C}$.

Total RNA extraction and hybridization Using Trizol reagent (Invitrogen, Carlsbad, USA), total RNA was extracted from the cultured cells. To prepare fluorescent labeled cDNA, RNA was incubated with oligo-dT, $5 \mathrm{x}$ reaction buffer, $0.1 \mathrm{M}$ DTT, 10x dNTP, 
cy3-dUTP or cy5-dUTP fluorescent nucleotide (Amersham, Uppsala, Sweden), RNAsin, and Superscript reverse transcriptase (Invitrogen, Carlsbad, USA). Un-incorporated nucleotides in the prepared cDNA were removed using Bio-Spin column (Bio-Rad, Hercules, USA), and the cDNA was concentrated using a Microcon 30 column (Millipore, Bellercia, USA). After concentration of labeled cDNA, probe was added to poly (dA) yeast tRNA, human cot1 DNA and incubated at $99^{\circ} \mathrm{C}$ for $5 \mathrm{~min}$, and at room temperature for $5 \mathrm{~min}$. The samples were mixed with hybridization buffer (Genomic solution, Cambridgeshire, USA) and used to treat a cDNA microarray chips containing 14,080 genes. Hybridization was performed at $56^{\circ} \mathrm{C}$ for $14-16 \mathrm{~h}$, and then the array was washed by placing them into washing solution containing $1 \mathrm{xSSC}$, and $0.1 \%$ SDS for $10 \mathrm{~min}$ at room temperature (Xia et al., 2003).

DNA microarray scanning and analysis Microarray were scanned using an Arraywox scanner (Applied Precision Inc. Northwest Issaquah, USA), analyzed using ImaGene version 5.1 software (Biodiscovery, Segundo, USA), and normalized using Genesight 3.2 version software. Normalization was performed by using the subtract means and all genes. The data normalized by Genesight was compared using an M/A plot. Genes differentially expressed were identified by intensity differences, after subtracting the background intensity. Genes showing expression changes of at least 2-fold were selected, and these selected genes were clustered by the hierarchical method (Lee and Park, 2004).
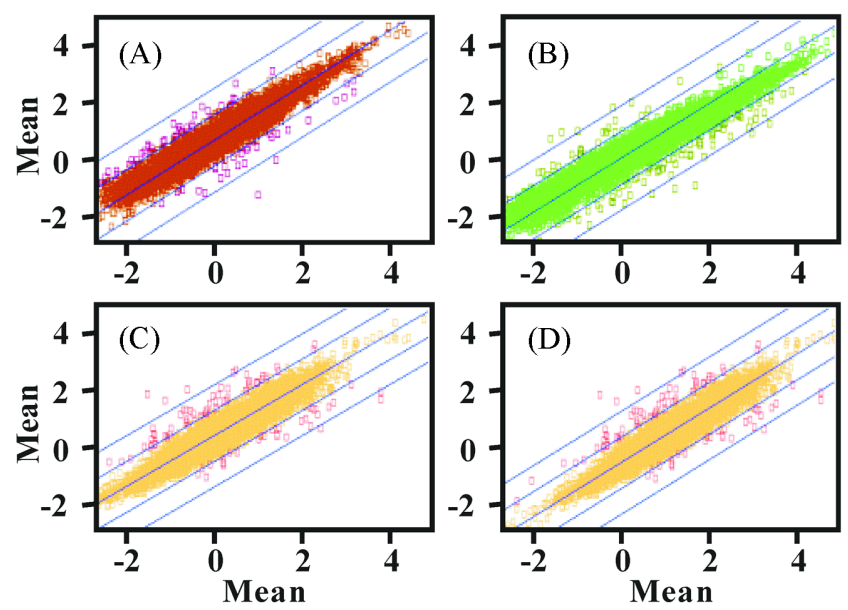

Fig. 1. The distribution chart of the mean ratio of the Cy3/Cy5 fluorescence intensity mean (log scale) of ADPKD patients microarray hybridization data. (A) and (B) Scatter plots for patient 1 performing each repeat experiment. (C) and (D) Scatter plots for patient 2 performing each repeat experiment.

RT-PCR Five $\mu \mathrm{g}$ of total RNA isolated from cultured cystic epithelial cells was used to synthesize cDNA by incubation with oilgo-dT, Superscript II reverse transcriptase (Invitrogen, Carlsbad, USA), 0.1 M DTT, and 10x dNTP. Synthesized cDNA was diluted

Table 1. The list of 25 genes commonly up and down regulated in cyst epithelial cells

\begin{tabular}{|c|c|c|c|}
\hline Acc \# & Gene ID & Function & Fold \\
\hline NT-002426 & matrix metalloproteinase 12 & cell motility & 0.23 \\
\hline ВC005809 & dual-specificity tyrosine-(Y)-phosphorylation regulated kinase 2 & unknown & 0.3 \\
\hline NM_012133 & coatomer protein complex, subunit gamma 2 & vesicle transport & 0.39 \\
\hline NM_006565 & CCCTC-binding factor (zinc finger protein) & transcription factor activity & 0.43 \\
\hline NM_005271 & glutamate dehydrogenase 1 & unknown & 0.45 \\
\hline NM_001845 & collagen, type IV, alpha 1 & extracellular matrix structural constituent & 0.48 \\
\hline NP_001785 & cadhedrin 4 , type $1, \mathrm{R}$ cadhedrin & cell adhesion & 1.26 \\
\hline NM_005429 & vascular endothelial growth factor $\mathrm{C}$ & cell proliferation & 2.08 \\
\hline NM_005926 & microfibrillar-associated protein 1 & extracellular matrix & 2.1 \\
\hline NM_006265 & RAD21 (S. pombe) homolog & apoptosis & 2.15 \\
\hline NM_005269 & glioma-associated oncogene homolog (zinc finger protein) & development & 2.21 \\
\hline NM_173075 & FE65-LIKE 2 & intracellular signaling cascade & 2.53 \\
\hline NM_000304 & peripheral myelin protein 22 & peripheral nervous system development & 2.59 \\
\hline ВC002934 & predicted osteoblast protein & unknown & 2.61 \\
\hline ВC002439 & tat-interacting protein $(30 \mathrm{kD})$ & apoptosis & 2.63 \\
\hline NM_003463 & protein tyrosine phosphatase type IVA, member 1 & $\begin{array}{l}\text { prenylated protein tyrosine phosphatase } \\
\text { activity }\end{array}$ & 2.63 \\
\hline AJ006291 & leucine-rich protein mRNA & unknown & 2.7 \\
\hline NM_001249 & ectonucleoside triphosphate diphosphohydrolase 5 & endoplasmic reticulum & 2.81 \\
\hline NM_002354 & tumor-associated calcium signal transducer 1 & unknown & 2.98 \\
\hline NM_000761 & cytochrome P450, subfamily I (aromatic compound-inducible & endoplasmic reticulum & 3.11 \\
\hline NM_002333 & low density lipoprotein receptor-related protein 3 & lipid transporter activity & 3.12 \\
\hline NM_000211 & integrin, beta 2 (ITGB2) & cell adhesion & 3.78 \\
\hline NM_000076 & cyclin-dependent kinase inhibitor 1C (p57, Kip2) & cell cycle & 4.02 \\
\hline NM_080284 & ATP-binding cassette, sub-family A (ABC1), member 6 & transport & 4.26 \\
\hline NM_000615 & neural cell adhesion molecule 1 & cell adhesion & 4.31 \\
\hline
\end{tabular}


and PCR was performed (Fatima et al., 2002). GAPDH primer was used as the quantitative control. PCR products were subjected to electrophoresis and the intensities of bands were measured using Gelpro analyzer software (Media Cybernetics, Spring, USA).

\section{Results}

The over-expression of the PKD2 gene The transfection efficiency of the PKD2 gene was confirmed by RT-PCR and immunocytochemistry (data not shown). To identify the function of the PKD2 gene, we performed cDNA microarray analysis on epithelial cells derived from cysts of ADPKD patients (cyst epithelial cells). The results of our analysis using Genesight are shown in Fig. 1. The distribution showed a centralized pattern. Nineteen genes were up-regulated genes. These included neural cell adhesion molecule 1, which plays an important role in many neuro-development processes. Six genes were down-regulated genes, including matrix metalloproteinase 12, the product of which is one of the most abundant proteins in tissue re-modeling after injury (Table 1).

M-A plot M-A plot allows the detection of the intensitydependent pattern of $M$; in $\log$ scale $M$ represents $\log _{2} R / G$. A represents $\log (\mathrm{RG})$ (Yee et al., 2002). Data were normalized using Lowess analysis (Christopher et al., 2002). Presently, the most commonly used value for describing a genes expression level is the ratio in $\log$ scale. The $\log _{2}$ ratio value, however, may be systematically dependent on the intensity. Locally weighted linear regression (Lowess) analysis has been proposed as a normalization method to remove intensitydependent effects that affect the $\log _{2}$ ratio value (John, 2002). M/A data plots are shown in Fig. 2.

Table 2. Twenty-eight commonly up- or down-regulated genes obtained by hierachical clustering

\begin{tabular}{|c|c|c|c|}
\hline Acc. \# & Gene ID & Function & Fold \\
\hline ВС005809 & dual-specificity tyrosine-(Y)-phosphorylation regulated kinase 2 & unknown & 0.3 \\
\hline ВC000498 & $\begin{array}{l}\text { glutamic-oxaloacetic transaminase } 1 \text {, soluble (aspartate ami- } \\
\text { notransferase 1) }\end{array}$ & amino acid metabolism & 0.37 \\
\hline XM_371951 & coatomer protein complex, subunit gamma 2 & vesicle transport & 0.39 \\
\hline ВC014267 & CCCTC-binding factor (zinc finger protein) & transcription factor activity & 0.43 \\
\hline ВС010264 & $\begin{array}{l}\text { splicing factor, arginine/serine-rich } 1 \text { (splicing factor 2, alter- } \\
\text { nate splicing factor) }\end{array}$ & pre-mRNA splicing factor activity & 0.45 \\
\hline AL157499 & homo sapiens mRNA; cDNA DKFZp434N2412 & unknown & 0.45 \\
\hline NM_139313 & YME1 (S.cerevisiae)-like 1 & unknown & 0.45 \\
\hline NM_013290 & GT198, complete ORF & unknown & 0.46 \\
\hline NM_199248 & calcium channel, voltage-dependent, beta 1 subunit & calcium ion transport & 0.46 \\
\hline AF020774 & $\begin{array}{l}\text { homo sapiens hair and skin epidermal-type 12-lipoxygenase- } \\
\text { related protein (ALOX12E) mRNA }\end{array}$ & unknown & 0.47 \\
\hline NM_199187 & keratin 18 & intermediate filament & 0.47 \\
\hline NM_006840 & $\begin{array}{l}\text { leukocyte immunoglobulin-like receptor, subfamily B (with TM } \\
\text { and ITIM domains), member } 2\end{array}$ & receptor activity & 0.52 \\
\hline NM_000712 & biliverdin reductase $\mathrm{A}$ & electron transport & 0.53 \\
\hline ВC024026 & transketolase (Wernicke-Korsakoff syndrome) & calcium ion binding & 0.55 \\
\hline ВC027946 & FE65-LIKE 2 & intracellular signaling cascade & 2.53 \\
\hline NM_153322 & peripheral myelin protein 22 & peripheral nervous system development & 2.59 \\
\hline NM_014888 & predicted osteoblast protein & cytokine activity & 2.6 \\
\hline XM_346206 & tat-interacting protein $(30 \mathrm{kD})$ & apoptosis & 2.62 \\
\hline ВС023975 & protein tyrosine phosphatase type IVA, member 1 & $\begin{array}{l}\text { prenylated protein tyrosine phosphatase } \\
\text { activity }\end{array}$ & 2.63 \\
\hline NM_201550 & leucine-rich protein mRNA & unknown & 2.7 \\
\hline NM_001249 & ectonucleoside triphosphate diphosphohydrolase 5 & endoplasmic reticulum & 2.81 \\
\hline ВC041789 & albumin & unknown & 3.04 \\
\hline BM433104 & $\begin{array}{l}\text { cytochrome P450, subfamily I (aromatic compound-inducible), } \\
\text { polypeptide } 2\end{array}$ & endoplasmic reticulum & 3.1 \\
\hline ВC007408 & low density lipoprotein receptor-related protein 3 & lipid transporter activity & 3.11 \\
\hline ВC005861 & $\begin{array}{l}\text { integrin, beta } 2 \text { (antigen CD18 (p95), lymphocyte function-asso- } \\
\text { ciated antigen 1) }\end{array}$ & unknown & 3.78 \\
\hline NM_000076 & cyclin-dependent kinase inhibitor 1C (p57, Kip2) & cell cycle & 4.02 \\
\hline NM_172346 & ATP-binding cassette, sub-family A (ABC1), member 6 & transport & 4.25 \\
\hline ВC014205 & neural cell adhesion molecule 1 & cell adhesion & 4.31 \\
\hline
\end{tabular}



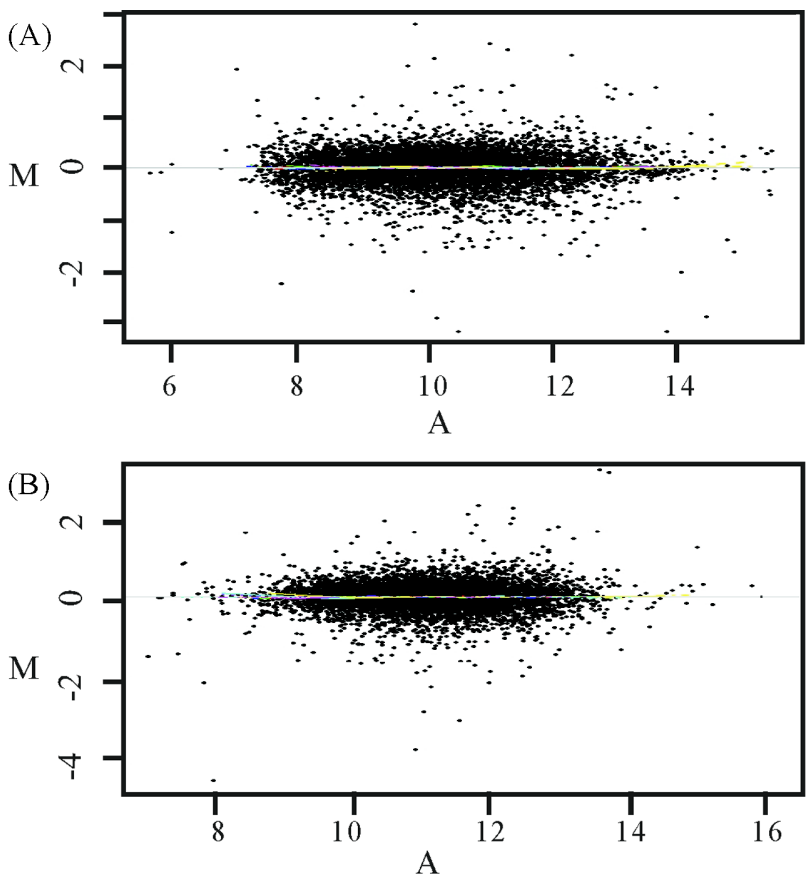

Fig. 2. M/A plot representation of ADPKD patients microarray hybridization data. (A) Scatter plots for patient 1 performing each repeat experiment. (B) Scatter plots for patient 2 performing each repeat experiment.
Clustering of DNA microarray data The subset of genes remaining after the removal of low quality genes was used to generate a dendrogram. Genes were grouped by complete hierachical clustering using Genesight 3.5 (Fig. 3), using the hierarchical clustering complete-link clustering algorithm (Herreo et al., 2001). This was calculated by measuring two points located far apart in different clusters part. Even though differences in gene downregulation were beween patients, three genes (aspartate aminotransferase I, coatomer protein complex and CCCTC-binding factor) were identified by hierachical clustering.

RT-PCR A specific PCR fragment of selected genes was successfully amplified by RT-PCR using selected gene primers of the expected size. Three up-regulated genes and one down-regulated gene were detected by DNA microarray and by RT-PCR. Tumor-associated calcium signal transduction, NACM, and MMP-12 were up-regulated. In contrast, cadhedrin 4, type 1, and R-cadhedrin were down-regulated in epithelial cells derived from severe cysts (Fig. 4).

\section{Discussion}

Our data demonstrate the usefulness of microarray analysis

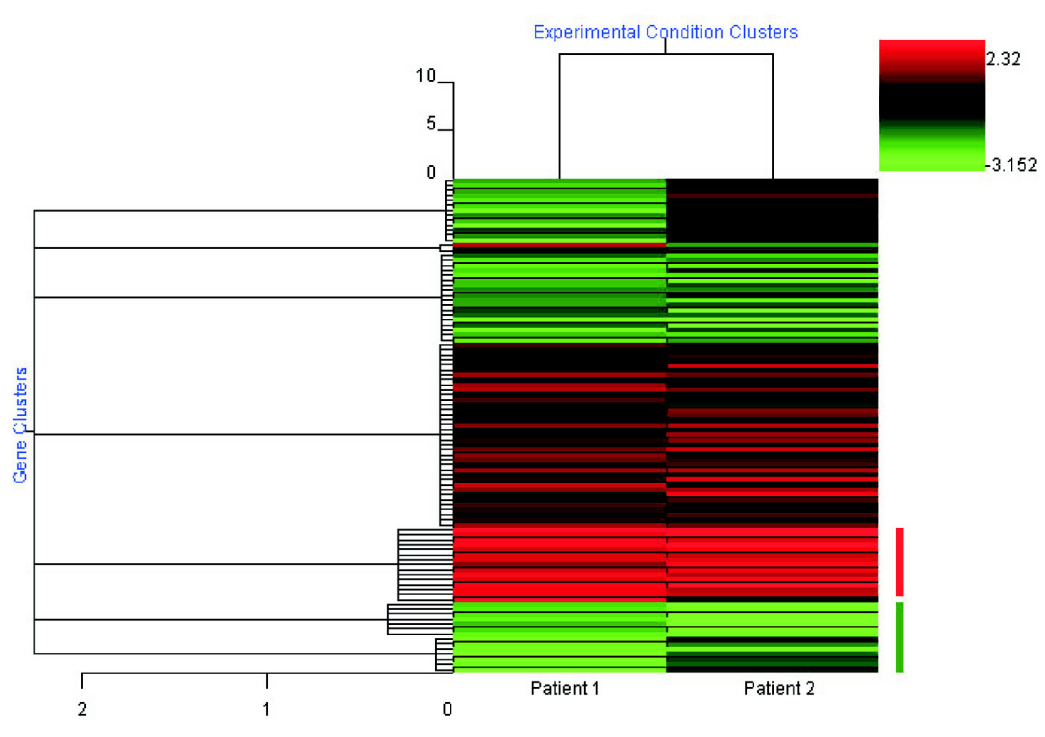

(A)

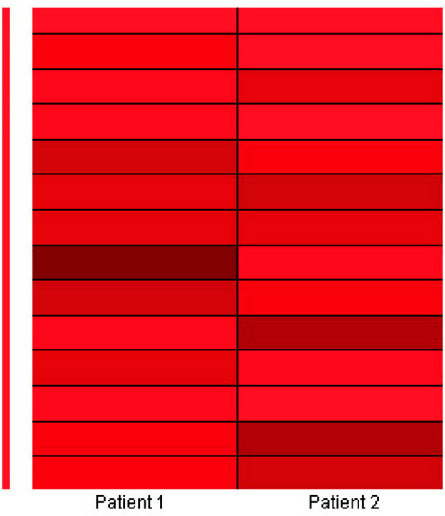

(B)

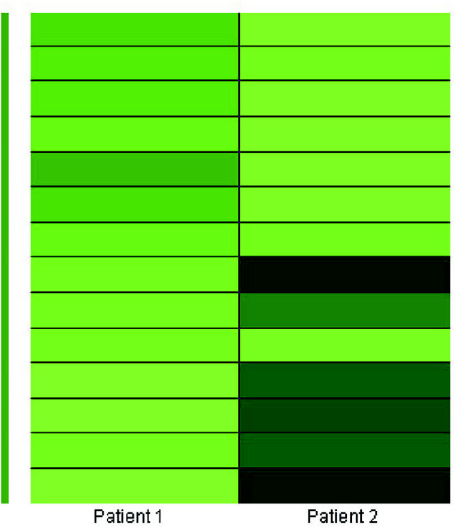

Fig. 3. Clusters of up- and down-regulated genes in two patients. (A) Up-regulated genes. (B) Down-regulated genes. 
$\mathbf{N}$

P1

P2

\section{1}

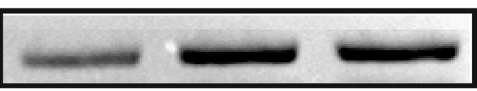

2

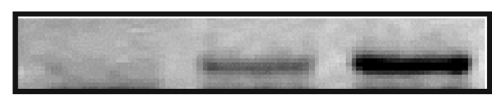

3

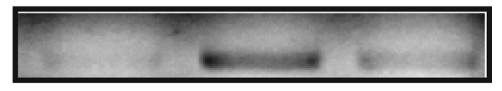

4

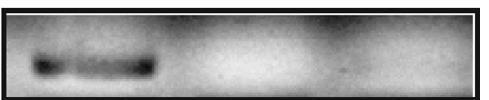

Fig. 4. The confirmation of candidate genes by RT-PCR. Lane N: Normal epithelial cell line, lane P1: ADPKD patient 1, lane P2: ADPKD patient 2, no 1: tumor-associated calcium signal transduction, no 2: neural cell adhesion molecule 1, no 3: cadhedrin 4, type 1, R-cadhedrin, no 4: matrix metalloproteinase 12.

for the determination of the gene expression pattern in human cyst epithelial cells. Apoptosis and differentiation in ADPKD tissue have been emerged, unlike normal tissue, but the pathway of cytogenesis was not characterized. To identify genes related to cytogenesis in ADPKD patients, we carried out cDNA microarray analysis of cyst epithelial cells derived from two patients. Microarray experiments were carried out on each sample three times. Image data was analyzed and clustered. Up- and down-regulated genes in epithelial cells were selected by comparing $\mathrm{X}$ and $\mathrm{Y}$ microarray data. Selected genes were also detected by semi-quantitative RTPCR. Using the public GenBank database, neural cell adhesion molecule 1 (a cell adhesion molecule that plays important roles in many neuro-developmental processes), cadherin 4, type 1, R-cadherin (all calcium dependent cell adhesion molecules), matrix metalloproteinase 12 (involved in tissue re-modeling and injury), and tumor-associated calcium signal transducer 1 (a growth factor receptor) were identified from sequence data. All four genes may be related to cell proliferation. We analyzed whole cyst epithelial cell lines in this study and not heterogeneous cyst cells. Thus we potentially investigated aspects of cyst formation, which is important because further functional studies may yield the mechanism of cytogenesis.

In summary, we determined the global gene expression profiles of cyst epithelial cells in biopsy samples obtained from tissue by using cDNA microarrays, which may be useful to identify genes related to cytogenesis in ADPKD.

Acknowledgment This research was supported by Sookmyung Women's University (2004).

\section{References}

Boulter, C., Mulroy, S., Webb, S., Fleming, S., Brindle, K. and
Sandford, R. (2001) Cardiovascular, skeletal, and renal defects in mice with a targeted disruption of the Pkd1 gene. Proc. Natl. Acad. Sci. USA 98, 12174-12179.

Christopher, W., Lars, J. J., Hanne, J., Randy, B., Laurent, G., Henrik, B. N., Hans-Henrik, S., Claus, N., Soren, B. and Steen, K. (2002) A new non-linear normalization method for reducing variability in DNA microarray experiments. Genome Biol. 3, 116.

DeRisi, J., Penland, L., Brown, P. O., Bittner, M. L., Meltzer, P. S., Ray, M., Chen, Y., Su, Y. A. and Trent, J. M. (1996) Use of a cDNA microarray to analyze gene expression patterns in human cancer. Nat. Genet. 14, 457-460.

Fatima, M., Dirk, G. and Edgar, S. (2002) A simple method for elimination of false positive results in RT-PCR. J. Biochem. Mol. Biol. 35, 248-250.

Guanqing, W. (2001) Current advances in molecular genetics of autosomal-dominant polycystic kidney disease. Curr. Opin. Nephrol. Hypertens. 10, 23-31.

Guanqing, W. and Stefan, S. (2000) Molecular genetics and mechanism of autosomal dominant polycystic kidney disease. Mol. Genet. Metab. 69, 1-15.

Hanaoka, K., Qian, F., Boletta, A., Bhunia, A. K., Piontek, K., Tsiokas, L., Sukhatme, V. P., Guggino, W. B. and Germino, G. G. (2000) Co-assembly of polycystin- 1 and -2 produces unique cation-permeable currents. Nature 408, 990-994.

Herreo, J. A., Valencia, A. and Dopazo, J. (2001) A hierachical unsuperuised growing neural network for clustering gene expression patterns. Bioinformatics 17, 126-136.

Lee, H. and Park, J. H. (2004) Informative gene selection method in tumor classification. Genomics Informatics 2, 19-29.

Lockhart, D. J., Dong, H., Byrne, M. C., Follettie, M. T., Gallo, M. V., Chee, M. S., Mittmann, M., Wang, C., Kobayashi, M., Horton, H. and Brown, E. L. (1996) Expression monitoring by hybridization to high-density oligonucleotide arrays. Nat. Biotechnol. 14, 1675-1680.

Malmendal, A., Halpain, S. and Chazin, W. J. (2003) Nascent structure in the kinase anchoring domain of microtubuleassociated protein 2. Biochem. Biophys. Res. Commun. 301, 136-142.

Masaki, K., Naohiko, S., Sumio, S., Katsuyuki, H., Yasuhiko, M., Masa-aki, M., Kozo, K. and Masato, N. (2001) Identification of sonic hedgehog-responsive genes using cDNA microarray. Biochem. Biophys. Res. Commun. 289, 472-478.

Michael, K. and Constantinou, D. (2000) Autosomal dominant polycystic kidney disease: molecular genetics and molecular pathogenesis. Hum. Genet. 107, 115-126.

Quackenbush, J. (2002) Microarray data normalization and transformation. Nat. Genet. 32, 496-501.

Schena, M., Shalon, D., Davis, R.W. and Brown, P.O. (1995) Quantitative monitoring of gene expression patterns with a complementary DNA microarray. Science 270, 467-470.

Silvia, G-P, Keetae, K., Cristina, I., Alicia, E. D., Elsa, Z., Marisa, B., Peter, C. H., Ignacio, L. R. M., Amin, A. and Horacio, F. C. (2001) Polycystin-2, the protein mutated in autosomal dominant polycystic kidney disease (ADPKD), is a Ca2+permeable nonselective cation channel. Proc. Natl. Acad. Sci. USA 98, 1182-1187.

van Adelsberg, J. S. (1999) The role of the polycystins in kidney development. Pediatr. Nephrol. 13, 454-459.

Xia, G., Xuping F., Tao L., Jian Z., Yao L., Qing W., Erliang Z., 
Yi, X., Yao, L. and Yumin, M. (2003) Determining a detectable threshold of signal intensity in cDNA microarray based on accumulated distribution. J. Biochem. Mol. Biol, 35, 558-564.

Yee, H. Y., Sandrine, C., Percy, L., David, M., Lin, V. P., John, N. and Terence, P. S. (2002) Normalization for cDNA microarray data: a robust composite method addressing single and multiple slide systematic variation. Nucleic Acids Res. 30, 15. 